\title{
Bride-Wealth: Is There Respect for Women in Manggarai, Eastern Indonesia?
}

\author{
Yohanes Servatius Lon; Fransiska Widyawati \\ STKIP Santu Paulus Ruteng Flores NTT, Indonesia \\ Corresponding Author: fwidyawati10@gmail.com
}

\begin{abstract}
This study explores the perspective of women in Manggarai, Flores Island in Indonesia, and the communaltraditional concept of bride-wealth as a symbol of respect for women. This study uses a qualitative approach by interviewing forty women, both married and unmarried. The respondents were asked their opinion regarding their imagination about bride-wealth and its influence on their courtship, engagement, wedding, and married life. The results indicated the presence of a gap between the social imagination of bride-wealth and the women's true experience. Most respondents stated how bride-wealth had strained their relationship and become a source of worry. The study therefore argues that bride-wealth as a sign of respect for women in Manggarai is merely a social imagination ingrained into the women's expectations. The study also indicates that education has changed the status of women and enables them to be independent.
\end{abstract}

Keywords: bride-wealth; marriage; women; discrimination; culture; tradition

\section{INTRODUCTION}

Marriage in Manggarai is not simply a commitment between two individuals but also the unification of two big families. Marriage creates a connection between two kin groups linked by the couple. The two kin groups are no longer strangers; they are now members of the new family called woé-nelu (family by marriage). Not only does marriage change the status of a man and a woman, but most importantly, it alters the status of the two families, i.e. the groom's family becomes the wife-receiver (anak-wina) and the bride's family becomes the wife-giver (anak-rona). The anak-rona has a blessing and cursing power over the anak-wina because the anak-rona has presented a woman for the anak-wina to live and prosper (Erb, 1999: 44; Lon and Widyawati, 2017b: 131-132).

The marriage procedure in Manggarai requires the active involvement of the family members and respected individuals in the village. Their participation becomes especially necessary because of the concept of bride-wealth (see also Kottack, 1994). Bridewealth was originally introduced to induce pride within the two families (anak-rona and anak-wina) and to strengthen their tie (woé-nelu). The more expensive the bride-wealth was, the prouder the two families would be (Sudi, 2016; Cangkung, 2016). Several studies done by Gordon (1975, pp. 215-216), Nggoro (2006p. 119), Ndung (2009), and Boylon (2009, pp. 201-202) argue that bride-wealth today functions also as a symbol of respect (hiang) for the bride. Bride-wealth also symbolizes the spirit of cooperation and signifies the legality of marriage, the right to have children, the stability of marriage, and the compensation for labor. Bride-wealth can come in the form of animals like buffalo and horse (paca), which is termed 'things outside the house' (pé 'ang tana) or it can be in the form of money (doi pongo) or also known as 'things inside the house' (oné mbaru) (see also Taylor, 1963: 72).

However, there have been debates on the role of bride-wealth in today's Manggaraian society. Many young people view bride-wealth more as a burden or even as a scourge (Wangkut, 2015). They are also 
dubious about the relevance of bride-wealth in this day and age. In addition, there have been many family issues related to bride-wealth, which adds to the skepticism (Gordon, 1975: 215-216; Boylon, 2009: 201-202).

This study discusses the function of bridewealth as symbol of respect for women in Manggarai. It focuses on the women's true experience dealing with bride-wealth as compared to their imagination. Using a qualitative approach, the author conducted interviews with more than forty women, both married and unmarried, asking about their ideas and their encounter with bride-wealth and its effect on their courtship, engagement, and marriage. This study aims to examine whether the customary ideal of bride-wealth is helpful to the women's personal experience, or whether bride-wealth de-emphasizes women's status in the patriarchal system of Manggarai.

\section{PREVIOUS STUDIES}

Many studies about bride-wealth have been carried out in other parts of the world. For instance, some scholars analyzed the impact of bride-wealth on women's reproductive autonomy and domestic labor (Dodoo and Frost, 2008). Furthermore, Ogbu (1978: 241-262) conducted a research about the function of bride-wealth and status of women in Africa. It argues that for the Africans, bride-wealth plays a role to validate marriage. Bride-wealth does not lower the status of the woman but strengthens her position within the society. Another study by Wojcicki, Straten and Padian (2010: 705-710) focused on the relationship between bride-wealth, sociodemographics, and sexual and reproductive practices among women in Harare, Zimbabwe. In this society, bride-wealth is viewed as a form of negotiation as a part of marriage procedure. They also found that women who were married with bride-wealth spent more years in education. Their male partners also tended to use contraception, causing them to have less risk of HIV infection.

Mulder (1988: 65-82) examined the correlation between bride-wealth and women's circumcision among the Kipsigis in Africa. Women who were married one or two years after circumcision generally received a higher value of bride-wealth as compared to those who were married more than two years after circumcision. The bride-wealth for younger women was also generally more expensive than that for older women. In Ghana, Fuseini (2013) studied the correlation between bride-wealth and women's autonomy with regards to fertility and personal matters. They discovered that bride-wealth had a great influence on the women's autonomy in both areas, but to a different extent. Another study by Sykes (2013: 97-117) in Papua New Guinea looked into the sisterbrother relationship in relation to bride-wealth. The study found that women presented their bride-wealth to their brothers to maintain the clan's pride.

A few studies have been done regarding bride-wealth in Manggarai, but none focused on the women's perspective. Kleden's article (2007) which discussed the influence of the patriarchal culture on gender as well as the role of the Catholic Church in changing the status of women and men in Flores does not elaborate on the issues of bride-wealth in Manggarai. A study by Madung (2012) based on his experience in meeting women who suffered from violence due to bride-wealth in Sikka, while similar to this study, does not focus on bride-wealth issues in Manggarai. It also fails to identify the controversy between the social imagination of bride-wealth and women's reality. John Gordon Lambert (1975) discussed the expense of bride-wealth in the 1960s to the 1970s in Manggarai and the worry of young men on their ability to pay. However, he did not consider the women's perspective at all.

\section{RESULTS OF STUDY}

This study explores the opinion of Manggaraian women about bride-wealth and the results are presented as follows.

First, bride-wealth and woman's existence. When asked if being female is directly associated with bride-wealth, the respondents agreed that people in Manggarai relate women with bride-wealth. When a girl is born, it is common for people to say, "The family will get a buffalo." If a family has many daughters, people normally comment, "The family will get many buffaloes (do kaba)." To console parents who have no sons, people will say, "Don't be sad, you will still get many buffaloes." When a girl is injured, people will say, "Be careful, don't get injured. It will decrease the number of buffaloes your family receives."

Most respondents in this study confirmed the above statements. Many also expressed that despite making a joke, the statements had conditioned them to think that female is associated with bride-wealth. They also admitted to using similar statements about their daughters. Some of the more educated respondents 
thought it was not right to make those statements about their children but still made them out of habit The imagination about bride-wealth is so compelling because it has been ingrained in them since they were young. However, there were varying responses about whether this social imagination makes them feel valued. Most often than not, the talk of bride-wealth only makes them uncomfortable.

Second, bride-wealth and courtship. This study found that women often find the concept of bridewealth worrisome even in the stage of courtship. The respondents admitted that the talk of bride-wealth did not commonly occur at the start of their courtship. However, as their relationship developed, they started to worry about bride-wealth. A respondent named Ms. $\mathrm{V}$ shared that as her courtship became more intimate, she started to fear that her family would ask for a huge amount of bride-wealth from her boyfriend's family. She was worried that the expensive bridewealth would strain their relationship or even shatter their love for each other (Lon and Widyawati, 2017a).

Another respondent, Ms. M, shared her traumatic experience growing up in a strict family. When her sister married, her father demanded an expensive bride-wealth from the groom. Her father coerced the groom with intimidating questions regarding his ability to pay for the bride-wealth. In the end the groom failed to pay the full amount of bride-wealth, which led to the father's fury. Ms. M was worried that her father would do the same to her boyfriend. She was especially worried because she received a higher level of education than her sister, which means that her father would be likely to expect a higher bride-wealth. In short, the thought of bridewealth had caused her much worry and stress.

In another case, Ms. R, a master's student, decided to get married before completing her study in order to avoid an expensive bride-wealth. She feared that her father would ask for an expensive bride-wealth if she were to get married after finishing her master's degree. She was also worried that her boyfriend would not be able to pay for the bridewealth, which would potentially lead to a break-up.

When the respondents were asked if they were satisfied with their bride-wealth, they responded that they were only slightly pleased because it gave them pride and profit to a small extent. They generally expressed worry as bride-wealth affected their relationship. It goes to show that bride-wealth as a symbol of pride for a woman and her family is only a social imagination because in reality, women are faced with fear and stress even in their courtship stage. Third, bride-wealth and engagement. In Manggarai, the marriage procedure begins with an engagement ceremony. It is also the time to discuss bride-wealth. During that time, the speakers (tongka) of the two families would negotiate on the ideal amount of bride-wealth. The man typically sits with his family members to witness the discussion. On the other hand, the woman must wait in the bedroom. She is only allowed to come out when an agreement has been reached. If the bride-wealth is settled well, the two families would celebrate with the ritual of ring exchange. It is the symbol that the man and woman are officially engaged. The amount of bride-wealth is usually determined by parents without consulting the bride. It depends greatly on the social and economic status of the two families and the deemed "quality" of the woman. It will be expensive if the bride comes from a rich and highly-respected family or if the bride is deemed to be good-looking. Today, it also depends on the woman's level of education. A highly-educated woman would normally receive a higher amount of bride-wealth.

All married respondents in this study agreed that engagement was a very uncertain process for them; it was the time they felt most anxious because it was the first time for the two families to officially meet and talk about the bride-wealth. They feared that the discussion would not reach an agreement, relying only on prayers to calm themselves. Some of them were apprehensive that they tried to sneak out to the toilet or the kitchen to eavesdrop. Some even asked other girls to listen and inform them of the matter. The women would only feel relieved after the amount is settled.

This interview discovered several interesting cases in which the settlement of the amount of bridewealth had failed. In 2013, Mr. I who was a civil servant and his family came to propose to Ms. E who just finished her bachelor's degree. In Manggarai, a civil servant is considered well-off. Ms E's family asked for 250 million Rupiahs and several buffaloes and horses for bride-wealth. Mr. I's family attempted to bargain but to no avail. After two hours of discussion, an agreement could not be reached, and Mr. I's family left in disappointment (Lon and Widyawati, 2017a).

In another case, Mr. A, who came from a poor family, could not pay the bride-wealth for his girlfriend, Ms. J. He thus asked Ms. J to live together even before marriage, as parents tend to ask for a cheaper bride-wealth if the man and woman have been 
living together for some time. Unfortunately, Ms. J's father still demanded an expensive bride-wealth. The two families failed to settle the bride-wealth and the couple were not allowed to live together anymore. They were forced to go back to their parents even though they had lived together for some time.

The study made by Peter Hagul (2011) recorded cases of women who committed suicide after their bride-wealth agreement failed. Ms. M was one of them. She was frustrated when the two families failed to reach an agreement causing her boyfriend, Mr. J, to leave her. She took her own life by ingesting mosquito repellent. Her death became a proof that an expensive bride-wealth not only destroys love, but also life.

In this study, some respondents also recalled a story of Ms. M who committed suicide in 2014 after breaking up with her boyfriend due to failed settlement of her bride-wealth. Her friends recounted her crying every day and pushing everyone away. She was depressed and finally hung herself in her room (Lon and Widyawati, 2017a).

Every respondent in this study expressed a thought that the discussion about bride-wealth is too complicated and takes too much time. It is necessary for parents and the two families to consider the couple's feelings in their decision. Bride-wealth should not be a source of suffering to the couple. It should help them to strengthen their love for each other.

Fourth, bride-wealth and wedding ceremony. In Manggarai the wedding ceremony is separated into two stages. It begins with a traditional ritual (wagal) which takes place at night and is limited to the two big families and close neighbors. It is followed by a wedding mass in the church the day after. Wedding is a huge celebration in the region. Around 500 to 2000 invitations are usually sent out. The ceremony also requires a huge amount of money funded by both families. If the host of party (the bride's family) wishes to have a bigger celebration they may use the bride-wealth money presented by the groom's family. Hence, it is a problem when the bride-wealth presented is deemed insufficient. A heated debate or even a conflict could arise, which often disrupts the wedding day and threatens the harmony between the two families. Such disruption also greatly affects the bride emotionally.

One of the respondents, Ms. V, shared that a conflict between the two families broke out on her wedding day. It happened because her husband's family had not brought enough money. Her family was utterly disappointed and enraged because her parents had borrowed a lot of money to cover the cost of the party. They thought that they would be able to repay the debt using the bride-wealth money. During the wedding mass, her parents refused to talk to the groom and his family. During the party, they pretended to be busy welcoming the guests, but Ms. V believed they were hiding their frustration. The circumstance had left Ms. V in emotional turmoil during the wedding ceremony. After the wedding day, she was terrified to face her husband's family. She was worried that they would reprimand her. Every time she visited her husband's family, she felt insecure as everyone still talked about her bride-wealth. Moreover, her husband's parents forbade her husband from visiting her family. The tension between the two families lasted until she gave birth to her first child.

Some other cases even caused the wedding to be called-off. This unfortunate situation happened to one of the respondents, Ms. S, an elementary school teacher whose partner, Mr. S, was a farmer. Ms. S was already pregnant before her marriage. $\mathrm{Mr}$. $\mathrm{S}$ and his family thought that Ms. S' family would not demand an expensive bride-wealth because of her pregnancy. However, her family still asked for a huge amount of bride-wealth, to which Mr. S' family agreed to avoid humiliation. During the wagal ritual, they presented only half of the agreed amount. Ms.S' family was upset and forbade her to go to the church for the wedding mass by locking her in the room.

It was interesting that almost two-thirds of the respondents experienced some sort of conflict on their wedding day due to bride-wealth issues. However, most of them also managed to console themselves. They admitted that the key was to focus on their wish to have a joyful wedding and a happy life with their spouse.

Fifth, bride-wealth and married life.The impact that bride-wealth brings does not end on the wedding day. Through marriage, the wife must follow her husband's family system and leave her own. If she fails to observe the new customs, other family members would typically bring up the bride-wealth matters. It seems that bride-wealth justifies criticism of her behavior in the new family. The wife must endure humiliating questions about her bride-wealth posed by her husband's family. In a more extreme case, she is treated like purchased goods.

One of our respondents, Ms. E, shared her undesirable experience in her married life. She was initially happy to be married to her husband who was 
considered well-off. However, she was surprised when asked to do all the house work, which she had not expected. When she did not finish the house work, her mother in law would complain loudly that her bride-wealth was very expensive and yet her behavior did not match the price. Ms. E was hurt as she felt treated as an object.

The story of Ms. E is not so different from Ms. R's. She was married to $\mathrm{Mr}$. O, a civil servant. On their wedding day, Mr. O's family presented all the requested amount of money, buffaloes, and horses for the bride-wealth. However, when Ms. R came to stay in Ms. O's family after their marriage, she felt objectified. Her in-laws always demanded respect, while other members of her husband's family always commanded her to work. As she was not yet pregnant, her in-laws questioned her sexual life and blamed her as the root of the problem. His father-in-law even suggested that Mr. O should take another woman (See also Mbiti, 1975: 108). Ms. R felt depressed and helpless. She went for a medical checkup and treatment but to no avail. Ten years passed, and she still was not pregnant. She became burdened with the thought of getting a divorce. She hesitated because in the case of divorce, her family must pay back all the bride-wealth. Eventually, her parents sympathized with her and talked to Mr. O's family for divorce. Their marriage was ended when the bride-wealth was completely paid back to Mr. O's family. The study also found other interesting results. For example, some respondents admitted that they helped their husband to pay for the bride-wealth; they even took loans from the bank.

\section{DISCUSSION}

It is interesting that all respondents in this study believed in bride-wealth as a symbol of respect for women. However, their experiences indicated otherwise, with most respondents feeling worried and scared in dealing with their bride-wealth matters Some were disappointed, frustrated, and even committed suicide when agreement of bride-wealth could not be reached. Hence, there is likely a gap between the real experience of the women and the traditional perception and social imagination of bridewealth. This is likely associated with the passive role of women in the settlement of bride-wealth.

David Gauthier (1963: 119) defines respect as the willingness to consider wants, desires, commands, and enterprises of others. According to Darwall (1977), respect can be divided into recognition-respect and appraisal-respect. Recognition-respect refers to the willingness to give appropriate consideration in one's practical deliberations to the object, while appraisalrespect is the attitude of positive appraisal of a person on his/her merits. People who are respected have control over their lives and people who lack respect must rely on others to negotiate for them. Showing respect to someone means to act in a way that shows care about their feelings and well-being (Collier, 1988: 87). Respect requires one to pay attention and respond appropriately (Birch 1993). It also requires the acknowledgment of the power to demand, command, or to make claims on our attention, consideration, and deference (Feinberg, 1975). It is the recognition of something "as directly determining our will without reference to what is wanted by our inclinations" (Rawls, 2000: 153). You respect someone not because you want to but because you recognize that you have to (Wood, 1999).

According to Collier (1988: 76-77, 81-88, 97), respect becomes a central value because the structure of societies has social obligation in obtaining respect. For instance, as parents take care for their children's life, children must respect their parents. In the context of bride-wealth, Collier (1988, p. 97) states that respect is not determined by the amount of bridewealth but rather by the relationship between what is customarily given and what is actually given. Bridewealth demonstrates the cultural value of respect central to full adulthood. Hence, bride-wealth does not function as a symbol of respect for women but for their parents and their community. Mbiti (1969) argues that bride-wealth is not a form of payment but a symbol of gratitude of the groom's family to the bride's family for their care over her. However, Mutua and Chinchen (2006) explains that bridewealth as a wedding gift may guarantee that the husband values and cherishes his wife. Women may feel more valued by a man who pays bride-wealth for her because it indicates that the man is capable of caring for and supporting her (Wieland, 2004) or it confirms her attraction and desirability (Kenyatta, 1978). Moreover, women who marry with a bridewealth tend to have a greater respect in marriage than those without (See Ngubane, 1987). Mbiti (1969: 140; 1975: 108), Magesa (1997: 122), and Waruta (2005: 107) even argued that bride-wealth was more of a way of fostering women's dignity than a payment for her and her parents.

In the Manggaraian society, as in any 
patriarchal society, the decision was always made by the elders and the men. Women are considered as ata pé'ang (outsider) and men as ata oné (insider). The terms ata oné and ata péang emerge from the perspective of a patriarchal society that views men as leaders of the community. In Manggarai, only men can become tu'a golo (headman), tu'a teno (chief of land), tu'a panga (head of the extended family), tu' $a$ kilo (head of the nuclear family), tongka (speaker in marriage proposal), or tudak/torok (leader of a prayer/ ritual). Every major decision and every social or religious ritual is also led by men while women and children are mere passive spectators. Consequently, as ata oné, a man is considered as the owner and the successor of the clan. He has the right, and is even required, to stay in his parents' village after being married. A woman as ata péang must leave her family to live within her husband's village after being married. Through marriage, a woman leaves her parents' clan and becomes a member of her husband's clan. It is symbolized by a ritual of taking her first step in her husband's village on top of an egg and cracking it open (Erb, 1999p. 46). Through this ritual, the woman announces that she officially leaves her parents' customs (ceki) and follows her husband's custom. She does not belong to her parents anymore but to her husband and his family. In the new clan, she has no right over her children because they belong to her husband and his clan. A woman is considered as outside person who belongs to men (her father or her husband). In this case, a woman's status can only change from being her family's possession to being her husband's possession.

This difference in status between men and women affects their rights and responsibilities, as well as their roles in marriage. Beauvior (1974) claims that because men view women as fundamentally different from themselves, women are reduced to the status of the second sex and hence subordinate. In Manggarai, a man as the clan owner has an important role of regeneration of the clan. Meanwhile, a woman is only seen as a means for a man to reach this goal. As a result, the woman always receives the blame when a marriage fails to bear children (Boylon, 2012, p. 200). Every man must have children; otherwise, he is risking the longevity of his clan. A man is therefore allowed to take a second wife if his first wife fails to bear children.

The strong patriarchal concept of family in Manggarai affects the autonomy of women. According to Walby (1990, p. 20), patriarchy is a system of social structures and practices in which men dominate, oppress and exploit women. The idea of ata oné and ata péang potentially leads to gender discrimination. It keeps women away from the power systems, autonomy and self-determination. It also gives more room for husbands to dominate their wives and thereby creating a patriarchal system. Women's dependency and subordination to men is conditioned by a whole range of institutional practices embedded in the family. There is an expression, lami toni de weta (protecting sister's back), which means that men (brothers) must walk behind women (sisters) to protect them (Erna Niman, Interview, 13 January 2016). This expression reflects a belief that men have more power to protect women, or women are perceived as the weaker gender. This reality further proves women's status as second-class members of the society.

The gap between the real experience of women and the communal perception about bride-wealth in Manggarai might indicate the superficiality of respect for women in a patriarchal society. It could also happen because the glorification of bride-wealth as a symbol of respect had been instilled since they were little, even though the reality shows otherwise. Moreover, the idea that women who receive higher bride-wealth are more respected is likely untrue. Women do not even have a say in deciding her bridewealth; they are treated as passive spectators. This is especially because in the Manggaraian society, a woman is considered as an outsider who belongs to her father or her husband.

When the respondents were asked "Should the tradition of bride-wealth continue?" all of them surprisingly expressed that bride-wealth should be continued, especially in this day and age. Bride-wealth is necessary to prevent young people from living together before being officially married, as marriage is considered official only after bride-wealth is presented (Mbiti, 1975: 108). In this case, bride-wealth is a seal of relationship (Waruta, 2005: 107; Busieka, 2004: 4; Abwanda; 2004: 9). The payment of bride-wealth can also discourage divorce because bride-wealth is to be returned to the husband upon separation (Magesa, 1997: 122-127, Sakubu, 2003,: 12; Kottack, 1994; Wieland, 2004). Bride-wealth is also a sign of the man's commitment to marriage and his responsibility. It is an integral and indispensable part of the marriage process (Mbiti, 1975: 107, Magesa, 1997: 122, Waruta, 2005: 102; Leakey, 1977). 


\section{CONCLUSION}

Respect is valued in all societies, even though there are different standards and different consequences for having or lacking it. Bride-wealth is a good measure of the ambiguity of respect for women in Manggarai. Based on the traditional perception, bride-wealth functions as a symbol of respect for women. More expensive bride-wealth is associated with more respect. However, women have no voice in the process of bride-wealth negotiation in Manggarai. Hence, they cannot determine the course of events and lack both autonomy and power; and they of course lack respect. They suffer from worry, fear, insecurity, and frustration from the stage of courtship and even after the wedding.

Therefore, there is a gap between the social imagination and the personal experience of women regarding bride-wealth. This gap is arguably caused by social and cultural roots in patriarchy. In Manggarai, women are considered as outsiders, which illustrates their lack of rights. Women do not have a right over themselves because they belong to their parents and their husbands, since young females are conditioned to associate their worth with bride-wealth. The idea of bride-wealth as a symbol of respect has always been emphasized and instilled in them despite the unpleasant reality.

In this study, the respondents represent the change in how women perceive themselves within the patriarchal community. All respondents hoped that women would play a more significant role in the process of bride-wealth settlement. They hope to have more autonomy while still adhering to the custom of bride-wealth. They are aware of the duality of their identity as Manggaraian women, where they are free individuals and where they belong to the community at the same time. Therefore, the Manggaraian women need to be careful in managing their personal lives, especially in the case of relationship and marriage.

The study also indicates that education has changed the status of women and enables them to be independent. It is worth noting that the respondents were educated women living in town with good jobs. Education encourages women to recognize themselves as human beings with equal opportunities as men. Education gives a place for women to exercise their rights of speech, expression, and autonomy. Through education, women liberate themselves from patriarchy and are able to take care of their bodies and lives. Through education, women are also able to recognize their equality with men in marriage and not as mere objects for exchange between clans.

This study challenges the culture to make the bride-wealth more sympathetic to women. This can possibly be achieved through the following three requirements of good and respectful bride-wealth. First, the bride and the groom must be perceived as subjects and not objects in the process of determining bride-wealth. This means that the final decision must lie in their hands, and not in the hands of the male elders. Second, bride-wealth should not burden the bride and the groom in their married life. Therefore, the amount of bride-wealth should match the ability of the groom's family to pay. Third, the bride-wealth should be presented for the new couple, not for their parents or large extended family. However, is this perhaps too much to ask? In a patriarchal society as Manggarai, it is hard to imagine these changes taking place soon. Even so, we must remain hopeful that women will find a more respected place in Manggaraian society.

\section{REFERENCES}

Abwanda, O. J. (2004). Marriage and Widow Inheritance in the Luo Culture. A Challenge to Evangelization from the Perspective of Communication. Nairobi: Long Essay.

Beauvior, D. S. (1974). The Second Sex. Vintage Books: New York.

Birch, T. H. (1993). Moral Considerability and Universal Consideration. Environmental Ethics, 15(4), 313-332.

Boylon, Y. S. (2012). Perkawinan menurut Adat Manggarai: Dalam Perspektif Hukum Gereja Katolik. In M. Chen and C. Suwendi (Eds.), Iman, Budaya \& Pergumulan Sosial. Jakarta: Penerbit Obor.

Boylon, Y. S. (2009). The Controversy of Belis in Manggarai. Jurnal Pendidikan dan Kebudayaan: MISSIO, 1(2), 193-205.

Busieka, G. (2004). The Meaning of Bride Wealth in Traditional African Marriage, in Achola, P (ed). MIASMU Research Integration Papers to African Marriage and Family: Challenge and Change. Jan-April.

Collier, Jane F. (1988). Marriage and Inequality in Classless Societies. Stanford: Stanford University Press.

Darwall, S. (1977). Two Kinds of Respect. Ethics, 88, 36-49; reprinted in Dignity, Character, and SelfRespect, R.S. Dillon (ed.), New York: Routledge. Dodoo, F. N. A., and Ashley E. F. (2008). Gender 
in African population research: The fertility/ reproductive health example. Annual Review of Sociology, 34, 431-452.

Erb, M. (1999). The Manggaraians: A Guide to Traditional Life Styles. Singapore: Times Editions. Feinberg, J. (1975). Some Conjectures on the Concept of Respect. Journal of Social Philosophy, 4, 1-3.

Fuseini, K. and Francis N. A. D. (2013). I Bought You, I Own You! Bride-wealth and Women's Autonomy in Ghana. Ghana: University of Ghana.

Gauthier, David (1963). Practical Reasoning. Oxford: Oxford University Press.

Gordon, L. J. (1975). The Manggarai: Economic and Social Transformation in an Eastern Indonesian Society. Unpublished doctoral disertation. The Department of Anthropology Harvard University, Cambridge.

Hagul, P. (2011). Dowry Systems and Extended Family Networks: a case study in Manggarai and Nagekeo, Flores, Indonesia in Jones, Hull and Mohamad (eds). Changing Marriage Pattern in South East Asia. London: Routlege.

Kenyatta, J. (1989). Facing Mount Kenya. Nairobi: Kenway Publications.

Kleden, P. B. (2007). Perkawinan baru Antara Iman dan Akal Budi: Mas Kawin yang Terlampau Mahal". Ledalero, 6(2), 161-189.

Kottack, C. P. (1994). Cultural Anthropology 6th Ed. New York: McGraw-Hill Inc.

Leakey, L. S. B. (1977). The Southern Kikuyu Before 1903: Vol II. London: Academic Press

Lon, Yohanes and Widyawati, Fransiska (2017b). Cultural Aspects on Child's Development and Parenting in Manggarai, east Nusa Tenggara, Indonesia. Guidena Jurnal Ilmu Pendidikan, Psikologi, Bimbingan dan Konseling, 7(7), 131139; DOI: https://doi.org/10.24127/gdn.v7i1.959

Lon, Yohanes S. and Fransiska Widyawati (2017a). Belis dan Hari Perkawinan: Perempuan Dalam Budaya Manggarai, Flores. The $1^{\text {st }}$ International Conference on Social Sciences and Humanities (ICSSH). Jakarta: IPSK LIPI

Madung, O. G. (2012). Perempuan di hadapan hukum adat belis (Sebuah catatan dari Sikka-Flores). Unpublished manuscript.

Magesa, L. (1997). The African Religion: The moral Tradition of abundant life. New York: Orbis Books.

Mbiti, J. (1969). African Religions and Philosophy. London: Heineman Educational Books, Ltd.

Mbiti, J. (1975). Introduction to African Religion. (2nd ed.). Nairobi: East African Educational Publishers.
Mulder, M. B. (1988). Kipsigis Bride-wealth Payments, in L. Betzig, et al. (eds.) Human Reproductive Behavior: A Darwinian Perspective. Cambridge: U. Press. pp. 65-82.

Mutua, O. K. and Chidhen. D. (2006) Dowry in Africa: A Wife Purchased or Wife Cherished? Evangelical Mission Quarterly, Publication No 180280: January.

Ndung, Yustina (2009). Konstruksi Peran Politik Perempuan: Suatu kajian Struktur Partisipasi Politik Pertempuan Manggarai Flores dalam sketsa teori dan Refleksi pendekatan etnometodologi. Disertasi. Malang: Universitas Merdeka.

Nggoro, A. (2006). Budaya Manggarai: Selayang pandang. Ende, Flores: Penerbit Nusa Indah.

Ngubane, H. (1987). The consequences for Women of Marriage Payments in a Society with Patrilineal Descent. In Parkins, D. and Nyamwaya, D (Eds). Transformations of African Marriage, (pp. 173198). Manchester: Manchester University Press.

Ogbu, U. J. (1978). African bride-wealth and women's status. American Ethnologist, 5(2), 241-262.

Rawls, J. (2000) Lectures on the History of Moral Philosophy, Barbara Herman (ed.), Cambridge, Mass: Harvard University Press.

Sykes, K. (2013). Mortgaging the bride-wealth: Problems with brothers and problems with value. $H A U$ Journal of Ethnographic Theory, 3(2), 97-117.

Taylor, J. (1963). The accumulation of Capital. London: Routledge \& Kegan Paul.

Walby, S. (1990). Theorizing Patriarchy. Oxford, UK Cambridge, Massachusetts, USA: WileyBlackwell.

Waruta, D. W. (2005). Marriage and family in Contemporary African Society: Challenges in Pastoral Counseling, in Waruta, D.W and Kinoti, H.W (eds). Pastoral care in African Christianity, (2nd ed.), Nairobi: Acton Publishers. pp. 101119.

Wieland, R. (2004). Will marriage Work in Today's World? Kendu Bay, Kenya: Africa Herald publishing House.

Wojcicki, S. and Padian (2010). Bride-wealth and sexual and reproductive practices among women in Harare, Zimbabwe. AIDS Care, 22(6), 705-710.

Wood, A. W. (1999). Kant's Ethical Thought, Cambridge: Cambridge University Press. 